\title{
The Falklands: Rate of British Psychiatric Combat Casualties Compared Recent American Wars
}

\author{
Capt H H Price \\ MD*, US ARMY MEDICAL CORPS \\ Division Psychiatrist, Headquarters, 8th Infantry Division (Mechanised), US Army, Europe
}

SUMMARY: This paper examines factors leading to the low rate of combat psychiatric casualties in the British recapture of the Falklands compared to the American experience in North Africa, Italy, Europe and South Pacific theatres during World War II, the Korean Conflict and Vietnam. The factors compared are those thought to affect rates seen in these past wars. The factors highlighted are psychiatric screening of evacuees, presence of psychiatric personnel in line units, intensity of combat and use of elite units. Factors also mentioned are presence of possible occult psychiatric casualties such as frostbite and malaria, amount of indirect fire and the offensive or defensive nature of the combat. A unique aspect of the Falklands War examined is the exclusive use of hospital ships to treat psychiatric casualties and the impact of Geneva Convention rules regarding hospital ships on the classic treatment principles of proximity and expectancy. The types and numbers of various diagnoses are also presented.

The British Campaign in the Falklands produced a remarkably low rate of psychiatric casualties. Whem viewed in light of American experience in recent wars, this low rate represents a concentration of optimaf $\varnothing$ factors leading to healthy function in combat. The results of this war should not be used to predict a similafe outcome in future combat as this particular constellation of factors may not recur.

\section{Introduction}

The Falklands war is described by Surgeon Commander Scott-Brown, one of the Navy psychiatrists involved, as a 20th century reincarnation of the Afghan Wars or the 1896 Sudan Expedition ${ }^{1}$. Despite the technological advances of naval and air warfare in this conflict such as Exocet missiles and Harrier jets, the land war was fought without many of the weapons used in recent wars. There was little use of heavy armour or helicopter gunships. General Thompson, the land force commander, said "The only difference between Hannibal and us is that he went by elephant and we are going to walk"'. And walk they did, carrying most of their supplies, due to the poor road system on East Falkland.

During the course of the war which lasted a total of 74 days with a 25 day land campaign from the landing at San Carlos Water to the capture of Stanley, the British lost 237 men killed, 777 wounded with 446 receiving significant hospital treatment. The rate of evacuated psychiatric casualties was $2 \%$ of all wounded with 16 declared cases evacuated from the hospital ship, Uganda. This rate compares favourably to the American experience in recent wars, i.e., $23 \%$ of medical evacuees were psychiatric casualties

*The views expressed in this article are those of the author and do not purport to reflect the position of the United States Department of the Army, the Department of Defence or any other government agency. in WWII, $6 \%$ in Korea and $5 \%$ in the early stage of the Vietnam War, reaching a high of $60 \%$ during the drug epidemic of $1972^{3,4}$. The Falklands pro duced a low rate of psychiatric casualties. This papeg will examine the factors which the American ex perience suggests affects psychiatric casualty rates two of which were not present in the Falklands and six factors which were.

\section{Factors not Present}

The low psychiatric casualty rate in the Falklands is significant in that two factors believed to have decreased psychiatric casualties in American experiences were not present in this campaign, i.e. the presence of psychiatric personnel in line units and psychiatric screening of all evacuees.

Due to the psychiatric disaster in the American Army during the Tunisian Campaign in 1943, psychiatrists were sent to corps level, then further forward to evacuation hospital level during the Sicily Invasion. On 9 November 1943 the War Department re-established the position of division psychiatrist with the first division psychiatrist reaching a division at Anzio in March 1944. The increasing forward assignment of psychiatrists during World War 11 coincided with, and perhaps led to, a decrease in psychiatric casualties. However, even as late as August 1945, only seven out of 17 divisions in the Oo Southwest Pacific had division psychiatrists ${ }^{5}$. During Korea, within 6-8 weeks of the onset of fighting. division psychiatry became operational's. By the time 
of Vietnam, there were more psychiatrists in the theatre per Army troop strength than in any previous war. ${ }^{3}$ Though Abraham has written extensively on the treatment of battleshock (the British term for psychiatric combat casualties) and has proposed the development of Battleshock Rehabilitation Units at division level supported by Field Psychiatric Teams, these have not yet been fully organised ${ }^{6}$. There are no behavioural science teams attached to British line units corresponding to the division psychiatrist, psychologist, social worker, and enlisted behavioural science technician (91G) in the U.S. Army. No Royal Army Medical Corps psychiatrists were invited to the Falklands.

Psychiatric screening of medical evacuees has also been found to decrease rates of psychiatric casualties in the American Army. During the New Georgia Campaign in the Pacific during July and August 1943 no screening of evacuees occurred in the 43rd Infantry Division. This division had large numbers of psychiatric casualties as well as medical evacuees subsequently found to have psychiatric disorders at base hospitals ${ }^{7}$. This division lost $10 \%$ of its strength during one month due to N-P casualties. It is reported that men actually "tagged" and medically evacuated themselves to rear bases. In another division, the 37th Infantry Division, also on New Georgia and taking the same amount of physical casualties, all psychiatric cases were screened by the division psychiatrist producing a negligible N-P evacuation rate ${ }^{7}$. During the Korean War and the Vietnam War all psychiatric evacuees were screened by psychiatrists except for drug abuse cases evacuated from Vietnam through Drug Rehabilitation Centers run for the most part by internists or general medical officers ${ }^{4}$. No psychiatric screening occurred in the Falklands because the two Royal Navy psychiatrists present were aboard ship for the duration of the conflict, one aboard the hospital ship Uganda and one aboard the Canberra, a troopship with a 50-bed hospital ${ }^{8,9}$.

One was to have been placed in a mobile field hospital, but as all tents were lost in the sinking of the Atlantic Conveyor, the hospital was set up in a refrigeration plant at Ajax Bay primarily for surgical cases. All psychiatric casualties were evacuated to the Uganda. Though the British have a similar understanding of combat psychiatric casualties and their treatment ${ }^{10}$ as do American psychiatrists, the location of the psychiatrists was not optimal for the rapid return to duty of cases. The Geneva Convention prohibits return of troops to combat from a neutral territory and permits wounded to be taken prisoner from a hospital ship. Therefore casualties were sent by ambulance ship to the neutral port of Montevideo and then to Britain by aircraft. Once aboard the
Uganda at San Carlos Water the evacuee was as good as home in Britain despite the 8,000 mile distance.

The Canberra, on the other hand, was legally of troopship and thus a legitimate military target, by? Geneva Convention rules. Consequently after offload $\overrightarrow{\vec{s}}$ ing troops and equipment during the landings on $21 \mathrm{st}^{5}$ May and taking on some casualties it was sent the next day to the east of the Total Exclusion Zone out of range of land based Argentine aircraft. If the Bri $\overbrace{\bar{\Phi}}$ tish had been able to obtain complete air superiority the Canberra could have been kept closer to the lando battle medical evacuation chain and used for the treatment of psychiatric casualties and their returndirectly to combat.

Of the 16 psychiatric cases evacuated to the Ugan da, Scott-Brown reported that four were battleshock cases, four had formal psychiatric illnesses, precipita-1 ted by combat all of which were depressed, four werew curvivor reactions with bereavement and fear of minor trauma and four were cases of hyperventita tion and depression without exposure to land coळibat $^{1}$. The battleshock cases were treated with regt? warmth, food and small group therapy. The psychin-trist aboard took charge of a 250 bed low depein dency ward and performed many consultation-liaisôn? activities such as pain control consults and ampu这迎 tion counselling.

Surgeon Commander Morgan $0^{\prime}$ Connell, the psy chiatrist on the Canberra, consulted on eight cases: One was a case of bereavement, one with psychogmatic chest pain with family stresses, two cases of alcohol abuse, one case of acute paranoid schizo-ō phrenia with a previous history of hospitalization, twof homosexual civilian ship's crew members with de $\mathbb{\Omega}$ pression and a Senior NCO with disseminated $\underset{F}{=}$ sclerosis. He was also involved in preventive psychiatric group work with survivors of the Ardent aftersection, as well as the Special Air Service Squadrono which lost 19 men in a helicopter crash. Only the bereavement case had been involved in the land combat; his helicopter crashed and the pilot died in his arms under heavy fire from Argentines ${ }^{8}$.

Despite absence of psychiatrists ashore or in line⿻ units and the lack of psychiatric screening of evacuees all of which were removed from combat and senis to Britain, the Falklands Campaign still produced the remarkably low rate of $2 \%$ psychiatric cases of all medical cases. When viewed in the light of the $₹$ American experience in the past three wars, this low음 rate represents a concentration of optimal factors $D$ leading to healthy functioning in combat.

There are five optimal factors which appear impor- $n$ tant but first a look at an important factor which, while decreasing the rate of diagnosed psychiatric casualties, leads to their evacuation under other diag $-\omega$ noses. 


\section{Occult Psychiatric Casualties}

Marlow (1979) pointed out that during World War II "severe combat that produced few people who were labelled by the Medical Department as combat psychiatric casualties, also produced compensatorily large numbers of personnel withdrawn from battle for frostbite, illness or light injury, as well as AWOL and self inflicted wounds" 11 . The low number of psychiatric casualties in the British campaign may have been offset by the fact that $20 \%$ of all land casualties were due to immersion foot ${ }^{12}$. A number of exposure cases however, occurred when the landing ship, Sir Galahad, was bombed at Bluff Cove with no voluntary component to their condition. Therefore the number of occult psychiatric casualties may have been negligible.

In a climate very similar to the Falklands, when the 7th Infantry Division invaded Attu in the Aleutians in May 1943, large numbers of cold casualties occurred in a campaign lasting 21 days. This division, desert trained with neither proper training nor clothing for the cold wet weather, suffered $553 \mathrm{KIA}$, 1,154 wounded, 2,205 diseased, of which 1,518 were frostbite and trenchfoot. The North Pacific theatre had the lowest overall psychiatric casualty rate of the war $^{13}$. In the European theatre during World War II and again in Korea, frostbite was also noted to be an evacuation syndrome.

Evacuation of psychiatric casualties has occurred under organic diagnosis such as "blast concussion," and diarrhoea. In Italy after the invasion at Salerno in September 1943, the incidence of diarrhoea increased by one third in the 5th Army, "Most patients recovered promptly after three to five days regardless of whether sulfonamides, or bismuth or Paregoric were used"14. During this same period many patients who had bypassed evacuation hospitals and were evacuated to North Africa with diagnoses of "concussion" or other somatic disease were subsequently discovered to be neuropsychiatric casualties ${ }^{14}$. The ratio of diagnosed psychiatric casualties to battle casualties was one to eight. Later in the Italian campaign with more thorough evaluation the ratio rose to one out of four to five battle casualties ${ }^{14}$. At times command pressure influenced diagnosing of psychiatric casualties. On Guadalcanal in 1942 General Patch, commanding the Americal Division, insisted on courtmartialing officers with neuropsychiatric diagnosis. The division psychiatrist, serving also as the division surgeon, circumvented this by labelling these cases as "blast concussion" 15 . During the Iwo Jima campaign a high incidence of "blast concussion" evacuees occurred in Marine units. It was suspected that this was an attempt to decrease incidence of "combat fatigue"s.

Malaria during World War II was another example of an evacuation syndrome, preventable by taking Atabrine. On Guadalcanal in November 1942 so many men were lost due to malaria that all men with temperatures up to $103^{\circ}$ were ordered to remain in combat. This caused much resentment towards "healthy" N-P casualties" ${ }^{-\bar{p}}$. Again in the battle for Buna, New Guinea in 1942 the 32nd and 41 st Infantry Divisions, both without psychiatrists, overwhelmed forward treatment centers with malaria and diarrhoea cases $^{5}$. By December 1942 the Southwest Pacific theatre psychiatry consultant reported $42.7 \%$ of cases evacuated to the United States were psychiatric. In the past, when no possibility of evacuation existed, rates of psychiatric casualties and other evacuation syndromes were low. On Bataan in 1942 little psychiatric disease occurred despite heavy fighting. lack of food and inevitable defeat ${ }^{18}$.

During the Vietnam War most psychiatric evacuees were screened by the "K-O" teams. "Drug abuse became a kind of evacuation syndrome with most of these patients becoming casualties only on the base of the positive urine screening"'.

This paper will now examine five optimal factors in the American experience which were present if the Falklands War.

\section{Elite Units}

The British troops involved were from elite units such as the Marine Battalions, Special Air Service Regiment, Parachute Regiment, Special Boat Service Guards and Gurkhas. These units have been serving together for years, the majority having seen service in North Ireland. The men knew their leaders and vice versa; strong group cohesion existed. The units were not dispersed and they fought together. Similarly, low rates of psychiatric casualties have occurred in American elite units. During the breakout from the Anzio beachhead in Italy in 1944 the 1st Special Service Force, a brigade of American and Canadian volunteers suffered a minimum of psychiatric casualties while taking heavy physical casualties ${ }^{17}$. Also in Italy, the 100th Infantry Battalion composed of Japanese-Americans from Hawaii suffered 109 battle casualties in a two week period with only one psychiatric casualty $^{17}$. The 442nd Regimental Combat Team also made up of Japanese-Americans had a similar low rate $^{17}$. The three Airborne Divisions fighting in Europe during World War II never had a neuropsychiatric casualty rate higher than $5.6 \%$ of battle casualties ${ }^{18}$. It should be noted, however, that in the Vietnam War the rate of psychiatric casualties did not increase when regular Army volunteer troops were replaced by draftees in $1967^{4}$.

\section{Duration of Combat}

The Falkland land campaign lasted only 25 days. 
Brief duration of combat exposure has, in American wars, been associated with low N-P casualty rates. During the invasion of Saipan, in a campaign of short duration from 19 June to 12 July 1944, the 27th Infantry Division had relatively few cases of psychiatric illness consisting of $5.6 \%$ of all admissions despite intense combat and heavy physical casualties". The low incidence of "combat exhaustion" type cases of World War II during the Korean conflict has been attributed to the rotation policy for 12 months in the combat zone.

This factor alone cannot always be relied upon to produce low rates. 24 hours after the newly arrived American Division went on the offensive at Guadalcanal, one third of the 350 casualties at the clearing station were psychiatric ${ }^{7}$. Later during the New Georgia Campaign $70 \%$ of the total N-P casualties occurred during the first month, $26 \%$ in the second and $4 \%$ in the third and final month ${ }^{20}$. This decreasing incidence was due to improved screening of casualties but also due to the changing character of the combat as the island was cleared. On Okinawa, in April 1945, after an initial period of light combat and relatively unopposed landings the psychiatric casualty rate rose on the third day of intense combat ${ }^{18}$. Of 100 psychiatric cases evacuated to Saipan a large sub-group consisted of men with over 140 days combat in the theatre ${ }^{18}$. Psychiatric casualties can occur early in a campaign in men with previous combat.

\section{Indirect Fire}

In American wars the presence of indirect fire is associated with increased N-P rates. The British force experienced limited heavy bombardments, no intense counter-attacks, and intermittent air attack. Few psychiatric casualties occurred while the Task Force was at sea despite the threat from Exocets and Argentine fighters. Similarly, during the voyage to Okinawa no psychiatric problems arose in troops due to the heavy Kamikaze attacks ${ }^{18}$. However, once landed at Okinawa $13.3 \%$ of all admissions were psychiatric cases. This was attributed to concentrated heavy artillery fire $^{18}$. At Anzio the rate of N-P casualties rose in support troops for the first time due to heavy continuous bombardment of the surrounded beachhead ${ }^{17}$. Later in Italy, the 88th Infantry Division in 22 days of combat in the Voltera area was under severe artillery fire and the N-P casualty rate was $24 \%$ with a incidence of diarrhoea as wellit. Lack of exposure to artillery barrages has been suggested as one factor in the low psychiatric casualty rate in American troops in Vietnam ${ }^{3}$.

\section{Unopposed Landing}

The most vulnerable moment for the British was

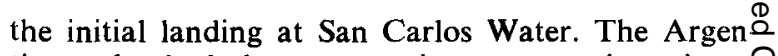
tines who had the opportunity to move in units tof oppose the landing did not take the initiative. Heavyo fighting at the beachhead as at Anzio and Salerno? leads to heavy physical casualties and psychiatries casualties. When the 31 st Infantry Division invade $\vec{b}$ Mindanao at the Parang beachhead in the Philippines $25 \%$ of the initial 400 casualties were psychiatric ${ }^{10} \frac{\bar{\sigma}}{.5}$

\section{Offensive vs Defensive Posture}

The British were constantly on the offensive in $\vec{a}$ mobile fluid advance primarily fighting with light $\overrightarrow{-}$ infantry weapons. After the improvised battle af Goose Green in which the 600 men of 2 Para Battalion captured 1,400 Argentines while losing thei: Commanding Officer, it was decided by the British? command to fully prepare for the final assault on the defensive perimeter around Stanley where the Argen tines had withdrawn.

Rapidly advancing troops experience low psych tric casualty rates. During 3rd Army's sweep acress France in August 1944, the rate of psychiatric casum- ties was $7.4 \%$ of non-fatal casualties ${ }^{21}$. In Italy d $\mathrm{d}$. ing the pursuit to the Gothic line, the advancing 34R Infantry Division troops had low rates of psychiatân breakdown despite severe physical fatigue in fo days of marked fighting alternating with periods of go $0^{\circ}$ fighting during which it took heavy physical casualties. Under favourable tactical circumstances, even in 妻舫 presence of severe fatigue and wounded rates, lops N-P rates tend to occur.

In Vietnam as the posture changed from offensive operations to more defensive withdrawal the rate of $\frac{\mathscr{D}}{\mathscr{Q}}$ psychiatric casualties increased despite the overall de $-\overrightarrow{\overrightarrow{0}}$ crease in combat participation.

\section{Summary}

The low rate of British psychiatric casualties in the Falklands was due to a number of positive factors: The use of elite units, short duration of combat, little exposure to indirect fire, an unopposed landing and $a \stackrel{\infty}{\rightleftharpoons}$ consistently successful offensive posture, all of which influenced the rate of psychiatric casualties in past 3 American wars. This low rate occurred despite the absence of any psychiatrists on land during the cam-응 paign and the absence of psychiatric screening of evacuees. The combination of favourable factors oc- 9 curring in this conflict is not likely to occur in the most predictable future American conflict, a high intensity European war. The low rate of psychiatric $N$ casualties experienced by the British should not de- $N$ crease planning and training for dealing with these casualties in any future conflict involving either the British or U.S. Army. 


\section{REFERENCES}

1 Scott-Brown A. Presentation, Symposium on Military Psychiatry. Royal Army Medical College, Millbank, Sept. 30, 1982.

2 Sunday Times of London Insight Team. War in the Falklands: The Full Story. Harper and Row, New York, 1982.

3 Tiffany, W J and Allerton, W S. Army Psychiatry in the Mid-60's. Amer J Psychiat 1967; 123: 812-813.

4 Jones, F D And Johnson, A W. Medical and Psychiatric Treatment Policy and Practice in Vietnam. J Soc Issues 1975; 31 (4): 49-65.

5 Challman, S A and Davidson, H A. Southwest Pacific Area, in Glass, A J and Mullins, M S (eds). Neuropsychiatry in World War II, Vol II, Overseas Theatres. Washington DC, U.S. Government Printing Office 1973; 513-577.

6 Glass, A J. Psychotherapy in the Combat Zone. Amer J. Psychiat April 1954; 725-731.

7 Billings, E G. South Pacific Base Command, in Glass, A J AND Mullins, M S (eds), Neuropsychiatry in World War II, Vol II, Overseas Theatres. Washington DC, U.S. Government Printing Office $1973 ; 473-512$.

8 O'Connell, M. Psychiatrists at War. Paper presented at Symposium on Military Psychiatry, Royal Army Medical College, Millbank Sept 30, 1982.

9 Rottersman, W and Peltz, W. Western Pacific Base Command, in Glass, A J AND Mullins, $M$ S (eds). Neuropsychiatry in World War II, Vol 11, Overseas Theatres, Washington DC, U.S. Government Printting Office 1973; 59-621.

10 Agraham, P. Training for Battleshock. J R Army Med Corps 1982; 128: 18-27.

11 Marlow, D. Cohesion, Anticipated Breakdown, and Endurance in Battle. Considerations for Severe and High Intensity Combat. Unpublished, Dept of Military Psychiatry, Walter Reed Army Institute of Research 1979; p 14.

12 Lessons of Falklands: Prepare for Surprises. U.S. Medicine Feb. 1, 1983; p 3.

\section{Footnote by:}

\section{COLONEL P ABRAHAM L/RAMC FRCPsych}

\section{Professor of Military Psychiatry}

Captain Price was obliged to refer to "the rate of evacuated psychiatric casualties" as " $2 \%$ of all wounded" since these were the only data available to him. The true figure for incapacity for psychological reasons was approximately four times that number.

The principal reason for this was that many were evacuated with a physical label, a case of hysterical deafness diagnosed subsequently in UK being fairly typical.

Others avoided going through the evacuation
13 Frank, $\mathrm{R}$ L. Alaska and the Aleutians (North Pacific Area), in Glass, A J and Mullins, M S (eds), Neuropsychiatry in World War II, Vol II, Overseas Theatres, Washington DC, U.S. Government Printing Office 1973; 681-737.

14 DraYer, C S AND Glass, A J. Italian Campaign (9 September 1943-1 March 1944), Psychiatry Established at Army Level, in Glass, A J and Mullins, M S (eds), Neuropsychiatry in World War II, Vol II Overseas Theatre, Washington DC, U.S. Government Printing Office 1973; 25-45.

15 Kaufman, M R and Beaton, L E. South Pacific Area in Glass, A J and Mullins, M S (eds), Neuropsychiatry in World War II, Vol II, Overseas Theatres, Washington DC, U.S. Government Printing Office 1973: 429-471.

16 Beaton, L E and Kaufman, M R. As We Remember It, in Glass, A J and Mullins, $M S$ (eds), Neuropsychiatry in World War II, Vol II, Overeas Theatres, Washington DC, U.S. Government Printing Office 1973: 739-797.

17 Glass, A J and Drayer, C S. Italian Campaign (1 March 1944-2 March 1945), Psychiatry Established at Division Level, in Glass, A J AND MULLiNS, M S (eds), Neuropsychiatry in World War II, Vol lic Overseas Theatres, Washington DC, U.S. Govern ment Printing Office 1973: 47-108.

18 Markey, O B. Tenth U.S. Army, in Glass, A AND Mullins, M S (eds), Neuropsychiatry in World War II, Vol II, Overseas Theatres, Washingtorh DC, U.S. Government Printing Office 1973: 639-679

19 Kaufman, M R. Central Pacific Area, in Glass, A f AND Mullins, M S (eds), Neuropsychiatry in World War II, Vol. 11, Overseas Theatres, Washington DC U.S. Government Printing Office 1973: 579-592.

20 Hallam, F T. War Neurosis-Report by XIV Corps Surgeon, in Glass, A J AND Mullins, M S (eds), Neuropsychiatry in World War II, Vol II, Overseas Theatres, Washington DC, U.S. Government Printing Office 1973: 1063-1069.

21 Thompson, L J, Talkington, P L and Ludwig, A O. Neuropsychiatry at Army and Division Levels, in Glass, A J and Mullins, M S (eds), Neuropsychiatry in World War II, Vol II, Overseas Theatres Washington DC, U.S. Government Printing Office 1973: 275-373.

chain by virtue of recovery before being caught up in it, or because the sudden armistice forestalled the need for transportation as a casualty.

Concerning the possibility of occult psychiatric casualties occurring amongst those with cold injury, this was indeed not unknown, but the number may well have remained small because responses to cold stresses of one sort or another were managed within the unit wherever possible, which happens to be the correct procedure for overt psychiatric casualties as well. 